\title{
Upgrading EFL Teachers' Quality through an Online Mentoring System, an Innovative In-Service Training Model: The Case of Indonesia
}

\author{
Zifirdaus Adnan \\ University of New England, Armidale, NSW, Australia \\ E-mail: zadnan@une.edu.au
}

\begin{abstract}
Many studies have been conducted in English as a Foreign Language (EFL) teacher education to improve teachers' quality, and some of these have been on mentoring teachers, with the purpose of improving teaching of English as a Foreign Language (TEFL). However, TEFL teaching is still problematic worldwide including in Indonesia. Indonesian TEFL is seriously problematic because the expected levels of competencies are not adequately achieved. A major factor, teacher quality, is at issue. Even though the Government has provided models of training for its teachers, they have not been effective. This paper addresses this issue and proposes an innovative but cheaper mentoring system. This system also overcomes the shortcomings of the existing models of in-service training including its ad hoc nature, lack of practice and feedback, and lack of the opportunity to upgrade poor English skills. The paper argues that the system can overcome these issues, and Indonesia is capable of running the system with its existing resources. The model could be adapted to address similar TEFL issues found elsewhere.
\end{abstract}

Keywords: English as a Foreign Language; TEFL; EFL teachers; in-service training; online mentoring system

\section{INTRODUCTION}

There is little doubt that English language teaching in secondary schools is considered important worldwide, including in Indonesia. It has become more urgent these days with the increased globalization and free trade, with the implication that there will be a massive flow of information, people, and goods coming to Indonesia, which generates an immense amount of competition for Indonesians from other countries. To survive and win in such a competitive environment, Indonesia needs people with operational skills in English so that they can, not only consume imported goods and services but, more importantly, 'sell' theirs as well. However, the teaching of English in the country is still highly problematic (Widodo 2016, Raihani and Sumintono 2010, Nielsen 2003) as the outcomes are still 'far from perfect' (Sukyadi 2015, p.
162), in particular concerning the ability to speak and write in 'operational' English (Adnan, 2012).

There are many issues leading to the problem (Suryadarma \& Jones, 2013). One of the main issues is the problematic quality of teachers (Jalal, et al., 2009, Lengkenawati, 2005, Nielsen 2003), which forms 'the single most important factor in teaching quality because of the powerful influence their knowledge and skills have on student learning' (Barber and Mourshed 2007 as cited in Suryadi and Sambodho (2014, p. 144). In fact, teacher quality is considered 'a matter of serious concern in Indonesia' (2014, p. 144), and one reason being about $25 \%$ of them only completed secondary school level of education (the 2006 census, as cited in 2014). Although this figure concerns teachers of all subjects, there is evidence suggesting that many 
English teachers are no exception (personal notes). The weakness concerns knowledge in a range of necessary fields and skills including low competence in English language and cultural knowledge, a past pedagogic mind-set that is difficult to change, a lack of up-to-date knowledge about the curriculum and pedagogy because many of them, e.g. those who graduated prior to 2005, were not taught the recent approaches, concepts and theoretical bases employed in the recent curricula including 'competence' and 'genre approach'. Regarding teachers' competence in the English language, Indonesian teachers' skills are still lower than 'professional level' (Emilia, 2005, p. 9). On the issue of pedagogic mind-set, it seems that many Indonesian secondary teachers still stick to the old mind-set, the belief that teachers know everything and students are merely the absorbers of knowledge. Consequently, there is too little time allocated for student-centered activities to allow the students to acquire communicative skills (Bjork 2013). Their teaching is still focused on grammar instead of meaning despite changes of approaches in the national curriculum (Sudjana, 2000, as cited in Emilia, 2006, p. 9; Bismoko, 2003). For example, the introduction of competence-based curricula of 2004 and 2006, which adopt a genre approach to teaching, has not improved the results significantly, which explain, at least partially, why amongst millions of Indonesian students, who are required to take English lessons for six years, from Year 7 to Year 12, only very few are capable of using the language for a real oral and written communication at the end of Year 12. The Indonesian Governments have realized the issues and, therefore, have taken measures including providing in-service training, rewarding outstanding teachers and education professionals, and doubling their salary when they have completed a certification program However, the overall national data indicates that their competence and performance still have not been 'entirely satisfactory' although there has been some improvement (Ministry of Education and Culture, 2016, n.p.; Suharyadi and Sambodho, 2014). The next section reviews the current training models.

\section{THE EXISTING IN-SERVICE TRAINING MODELS}

Sumintono and Subekti (2014), who reviewed Indonesian in-service training and re-training since the independence (in 1945), summarize teacher training problems in four points: 1) the mismatch between the materials being presented and the teachers' classroom needs; 2) the absence of feedback for the teachers for their classroom implementation of the knowledge and skills gained in the training, as the courses are too short (e.g. two to three weeks); 3) the absence of teacher input regarding the content of the training (courses); and 4) prioritizing quantity over quality. A similar study by Raihani and Sumintono (2006) reports similar findings. Other studies discuss other problems including the lack of feedback due to the ad hoc and irregular nature of the current model and lack of time (Asep \& Sambodho 2014). The Government formed the Musyawarah Guru Mata Pelajaran or MGMP (Teacher Working Forum for High School Subjects), a forum for high school subject teachers within a cluster of schools to share knowledge and skills through its Quality Assurance Institute, the Lembaga Penjamin Mutu Pendidikan (Asep \& Sambodho 2014), but even this institute has not been successful due to factors such as lack of support from experts from provincial universities, school principals and local government (Evans at al., 2009, as cited in Asep \& Sambodho 2014). Besides, teachers are reluctant to share skills of good practices and resist changes, leaving the forum to be little more than a place for sharing lesson plans (Tedjawati, 2010, as cited in 2014, p.152).

In short, the results of the various measures to improve teachers' quality since 1945 have not been satisfactory since they have not improved students' performance significantly (Sumintono and Subekti, 2014), which implies that the country is in a serious need of an effective model of in-service training. The current Government has responded with a new initiative recently (2016), that is sending outstanding teachers, education professionals as well as art and cultural activists to countries with advanced progress in education overseas including Australia, South Korea, and New Zealand to attend a three-week training to improve their competence and performance. For this purpose, the Indonesian Ministry of Education and Culture (MOEC) (2016) had issued a tender document including the terms of reference (TOR). This document reveals that one of the main purposes is to change the teacher-centered mind-set (2016).

However, there is no guarantee that this model will be successful either for at least two reasons. Firstly, the training time is too short, only three weeks, and there is no certainty when the next one would take place. For the teachers, who for the first time are going overseas, at least one week would be making 
cultural and language adaptation visits to schools to observe and other recreational activities. Hence, only approximately two weeks are used for the actual training.

Moreover, since the training is largely theoretical as it involves no teaching practice with feedback, it is doubtful if the teachers would gain significant pedagogical and language skills from it because such an approach, known as 'transmitting knowledge', has been considered ineffective since a process of change in a teacher is more complex than that (Lee, Murphy and Baker, 2015; Yazan, 2015. See 'Theoretical framework' below). Lack of English competence amongst some of the participants could also limit the effectiveness of the training. Although a translator is employed, the issue of 'lost in translation' cannot be avoided.

Secondly, although the Government expects that these trainee teachers would pass on their knowledge and skills to other teachers at home, but this transfer of knowledge and skills is doubtful too, because after returning home the trainees would be busy with their teaching and other activities, while the other teachers would be busy with theirs too, and as mentioned earlier, teachers are reluctant to share knowledge and skills. Moreover, this overseas training is also expensive for the country.

\section{METHODOLOGY}

This paper is written based mainly on qualitative library and online research and the author's 30-years of language teaching experience face to face in both Indonesia and Australia, as well as online at two major distance education providers, Murdoch University in Western Australia and the University of New England in New South Wales. Supplementary information was collected from notes made at conference presentations, discussions with fellow educators, and from discussions with the author's Ph.D. students returning from their field research in Indonesia, all of which is referred to as 'personal notes'.

\section{THE DESCRIPTION OF THE MENTORING SYSTEM}

\section{The theoretical framework}

Before proceeding, it is necessary to present some theoretical foundations on which the model is developed. Mentoring has been used both to educate novice teachers (Mann \& Tang, 2012) and experienced teachers (Malderez, 2009). Many definitions have been proposed in the literature (Garvey, Stokes \& Megginson, 2014); hence selections must be made to suit the purpose, that is, to improve the knowledge and skills of English teachers at secondary schools in Indonesia and, at the same time, to propose an alternative to the existing in-service training models.

The basic meaning of mentoring is 'the process by which an expert person facilitates learning in the mentee through arrangements of specific learning experience' (Tovey, 1999, as cited in Rolfe-Flett, 2002, p. 2). Thus, the keyword here is 'to facilitate learning'. Learning is marked by a change in knowledge and skills to the better, so it has been part of teacher education. Theoretically, the current common view about the effective way of educating teachers is that of sociocultural, a significant departure from the assumption that transmission of knowledge from several fields including Applied Linguistics (AL), Language Teaching (LT) and Second Language Acquisition (SLA) to student teachers can make them capable of conducting effective classroom teaching (Yazan, 2015). This sociocultural theory has gained wider acceptance since Freeman and Johnson proposed it in 1998 (Lee, Murphy and Baker, 2015). The sociocultural theory suggests that the process of becoming an effective teacher is far more complex than simply transmitting knowledge. Yazan (2015:172) succinctly puts it in the following way: Sociocultural approaches view ESOL teacher learning as socially negotiated and situated in the context, and reliant on what they know about themselves as teachers, as well as their students, subject matter, curricula, and setting (Johnson, 2009). Thus, to ensure that the learning process happens successfully, one needs a longer time, practice, feedback and reflection as it involves many components.

Mentoring is also '.. an opportunity for colleagues to engage in reflective dialogue...' (Davies and Slattery, 2010). It is also 'a way of overcoming some of the shortcomings of current approaches' (Rodd 2006, as cited in 2010, p. 2). In short, the theory of mentoring employed in this article is a process of facilitation of learning in the mentees through a program, which aims at promoting learning experiences that provide an opportunity for the mentees to engage in updating and upgrading their knowledge and skills through activities such as discussion, reflective dialogues in English with experts and fellow teachers. The purpose of all of these is to overcome the existing shortcomings in their 
competence as EFL teachers. This definition fits the purpose of this proposed system: to overcome the current gaps in the quality of the teachers and at the same time to address the weaknesses in the current models of in-service training.

However, there is more to mentoring than that There are other features of mentoring that need to be included. Firstly, mentoring can be formal or informal, but the system is only about the formal type. A formal mentoring is conducted by an organization that 'supports and sanctions the mentoring relationship' (Davies and Slattery, 2010, p. 2). Such organization provides 'some level of structure, guidelines, policies, and assistance for starting, maintaining, and ending the mentor-protégé relationship' (Scadura and Pellegrini, 2007, as cited in 2010, p. 2). Secondly, to be successful, a formal mentoring program requires the input of high-quality trained mentors (Rod, 2006 , as cited in 2010, p. 2), and the program should be credible because it needs trust from the mentees. Both the mentors and the mentees must have a clear idea about the 'goals and obligations to each other by staying in touch and communicating with each other openly and transparently' (Kirner and Rayner 1999, as cited in 2010, p. 3).

Thirdly, traditionally mentoring is conducted face to face at a workplace. However, recently it has been conducted online as well (Singh, Allen and Rowan, 2017). Finally, it is assumed that carrying out a discussion of a subject in the target language is the best way to promote TL competence (State of Victoria, 2013), and a problem in understanding could be overcome by temporarily resorting to their first language. Finally, in this post method era (Brown, 2007), teachers should be able to employ the most appropriate method to achieve a specific objective.

\section{The proposed mentoring system}

The proposed system is based on the mentoring concepts and practices presented earlier. Mentoring is defined as mentoring EFL teachers through online virtual classrooms by two qualified mentors, with the focus on upgrading their competence in pedagogy and the subject matter for 20 weeks. Hence, the mentoring should be conducted in English by two qualified mentors for every group of four teachers; one of the mentors must be a specialist in Applied Linguistics (AL)/Language Education. The other does not have to be if unavailable since his/her task is only to concentrate on improving the English and cultural competencies of the mentees. Each of them mentors for two hours per session in alternate weeks on mutually agreed times. The material should concentrate on the problem areas discussed earlier including the concepts of competence and sub-competencies and genre approach, and other pedagogic aspects. Other material includes the teachers' own English teaching materials, especially those related to the Indonesian school curriculum, which they have to teach. All of these should be negotiated with the mentees at the beginning. The approach should be mentee-centered, conducting activities such as discussions, raising issues, asking questions, doing role-plays, experimenting with new methods and techniques in their classes and reporting back, conducting mutual class observations (if possible), demonstrating methods and techniques to gain feedback from the mentor and their fellow mentees, and writing a reflective essay, which should be examined by the mentor and given feedback.

Each component will be discussed below with an explanation of how the system addresses the weaknesses of the existing model and minimizes the major quality issues of the EFL teachers.

\section{The components of the system in details}

Using virtual classroom to mentor the teachers in their homes. This mentoring model is crucial to address two issues of the existing training models, namely, the issues associated with time and travel affecting both the mentors and mentees. For the mentors, spending two hours every two weeks from home to mentor teachers is much easier to do than traveling to rural areas required in the existing model, whereby they have to leave their families and work, for a period of four or more hours or even several days on the road. Such travels make it difficult to find adequate experts to give training, an issue that has been reported as an issue lacking experts to train teachers (Bjork, 2013). Similarly, it is also much easier and time efficient for the mentees to participate since they do not have to leave their classes to an unqualified substitute teacher or skip their classes if there is no one to substitute them. In short, this component eliminates two major problems found in the existing models, that is a lack of experts to train teachers in remote areas and the reluctance of the teachers to attend training because of both the travel and time required.

The use of qualified mentors. A qualified mentor is defined as an academic having the necessary pedagogic and English competence, experience in research and student-centered teaching, as well as an appropriate attitude to solve either one or both of the 
two categories of teachers' problems. He/she should also be willing to attend a workshop in preparation for the job. Each criterion is detailed below.

- An academic is defined as someone who has conducted research and published at least in a reputable national journal or completed an MA with some research experience, or a Ph.D. degree. Being an academic with at least some research experience is important in that they have reached some academic maturity, and therefore, have been able to expand knowledge, and to continue to do research to update their knowledge. They will also be able to read and discuss the recent pedagogic articles provided for the mentoring system.

- The academic must have the knowledge and skills in the English language at a professional level, that is he/she can communicate fluently in the language both orally and in writing. He/she should also have some substantial experience working with native speakers of English and has been exposed to English culture. The English skills are important to ensure that the mentoring class is run in English, and the mentor can help the teachers with their English teaching material. The experience in English culture is important to explain how the native speakers use the language.

- Competence in pedagogy is crucial for at least one of the two mentors for each mentoring group not only for the purpose that he/she has the adequate ability to help the teachers address their pedagogic issues especially how to conduct student-centered teaching to maximize the development of students competence, but also to ensure that the teachers have trust in him/her as a pedagogic mentor.

- The appropriate attitude is also crucial as this can affect the continuation and effectiveness of the program. The type of attitude needed is a strong dedication and commitment to improving the quality of teaching. A dedicated and committed person would seriously prepare and conduct the mentoring activities, whereas a person with a weak dedication and commitment would result in a weak quality of mentoring.

- Willingness to attend a workshop is important to make sure that the mentor understands the details of the mentoring program including the purpose, the approach, the methods, the curriculum, and the assessment.

This component, with the required criteria, can address at least two of the problems of the current training model, namely Problems 2, lack of practice feedback for teachers, and Problem 4, lack of opportunity to upgrade their English because with the mentors' fluent English and cultural background, they can address the major problems of weak English competence, and at least one of the mentors can overcome the weakness in pedagogic competence. Their experience with the use of English and its culture could also be a motivating factor for the teachers to attend the mentoring class since they can expect to upgrade their English competence from the fluent and culturally experienced mentors. An issue here is some of the mentors might not have high school classroom experience since, ideally, the mentors should have some. However, it is not essential because the mentees can share theirs with them.

\section{The curriculum focus and the methods of the mentoring system}

Since the focus of the activities is right on the materials closely associated with the main difficulties of the teachers i.e. the English and pedagogic competencies, this system directly targets the two main problems. With the twenty weeks of mentoring, the teachers have ample opportunity to clarify difficult concepts including language competence and sub-competencies, genre-based approach to teaching, student-centered teaching and different teaching methods and techniques, practice them and receive feedback. To improve their English, the teachers can bring their teaching material into the mentoring class and discuss the content and the effective methods of teaching it with the focus on developing student competence. The teachers should experiment in their class during the week, video it, and send the recording to the mentors and other fellow mentees to be discussed together and receive feedback allowing them to fine-tune their methods and techniques. This experience could give the teachers a significant amount of understanding about effective student-centered teaching and the skills to build student competence, and, since most activities are conducted in English, all the activities could also upgrade particularly the teachers' oral English skill. For the final assessment, the teachers should reflect on their experience and write an essay to demonstrate their pedagogic and English achievement. 


\section{ANALYSIS}

This specific problem-solution approach to upgrading teacher's knowledge and skills led for 20 weeks by qualified mentors, while providing a great deal of feedback, should be able to iron out the problems identified earlier, including the absence of effective feedback, the ad hoc nature, the mismatch between the material given in workshops and the actual classroom needs of the teachers.

Besides, there are other benefits of the proposed system over the existing model. Firstly, it is conducted in a small online class of four to five teachers per pair of mentors. Such a small group allows the mentees ample opportunity to be involved in in-depth interactions and discussions with the mentors using English, which provides an excellent opportunity, which they rarely have especially if they work in rural areas, to improve their skills. When it comes to a discussion of pedagogy, they also have more opportunities to practice their English. Secondly, it offers a more efficient and flexible use of time since they can attend it from home and can be conducted on any day and time of the week as agreed between the mentors and the mentees. This extended period could serve the mentees better than the two or three-week workshops in the current in-service training model because it gives the mentees a much longer period to learn, practice, and reflect.

Thirdly, compared to the three weeks overseas training the government has been offering lately, this mentoring system is much more cost effective and affordable as shown below.

\section{CAN INDONESIA AFFORD TO IMPLEMENT THE SYSTEM AND, IF SO, HOW?}

Arguably, it could because it has all the necessary components at its disposal. Firstly, concerning the availability of qualified mentors, indeed, there is no set of data available because this is a new program. However, if one takes overseas MA and Ph.D. graduates as an example because of their English skills and cultural experience, there are approximately 122,000 Masters-level graduates in Indonesia. If ten percent of them are qualified, they make 12,200 potential mentors; and there are also 21,000 Ph.D. graduates, and $10 \%$ of them make 2100 . The total is 14300 . If $30 \%$ of them are recruited, it will make at least 4290 potential mentors. If only $50 \%$ of them can be recruited as qualified mentors, this will make 2145 mentors. Since each mentoring group needs two mentors, these graduates can mentor 1072 groups. If each group consists of 4 mentees, Indonesia can upgrade 4290 teachers for just one year! It is a significant number. Besides these potential mentors, there should be more competent individuals in the communities (inside and outside Indonesia) who meet the criteria and wish to serve the country for just two hours per two weeks from their homes, e.g. retired teachers and lecturers, and NGO activists. Some could be recruited using Indonesian diaspora networks around the world. If these professionals are not applied linguists, they can concentrate on upgrading the teachers' English. They can mentor using much less cost compared to sending teachers overseas.

The second reason is the favorable regulations. Similar to universities in Western countries, the university regulation requires academic staff to carry out community service works besides teaching and research. Such service can be used as credit points to gain a promotion. The academics could claim mentoring teachers for points.

The third reason is that, through the government existing certification scheme, the Indonesian Government has doubled the pay for the academics that have completed the scheme. With the increase of salary, the government has reason to request a service in return. For those academics, who have been sent overseas using a government scholarship, the government would have further reason to ask them to contribute. The Government can use all these reasons to persuade those who are reluctant to participate.

However, the author believes there are many professionals who need no monetary incentive to serve the country. The 'Indonesia Mengajar' (Indonesia Teaches) project experience has shown that many Indonesians are willing to volunteer their service to improve education quality in the country, although they have to leave their 'comfort zones' and live in rural areas for a year (Indonesia Mengajar, 2017). The online mentoring system proposed here is not voluntary since some can still receive rewards in the form of credit points for promotion. In fact, the mentors, who are university academics, can gain at least three benefits: 1) credit points for conducting community service (for university lecturers); 2) financial benefit when promoted; and 3) an arena for practice to maintain and improve their English, especially their fluency since skills can deteriorate if not practiced. In other words, if there are many Indonesians who are willing to contribute for no monetary rewards and away from their homes, there 
should be more Indonesians who are willing to contribute to this mentoring work since they can gain more benefits for much less endeavor.

\section{The use of the existing facilities}

To successfully carry out the mentoring program, the mentoring organization needs facilities including an office, computers, the Internet and other office facilities as the center of operation. The government can meet all of these by just allocating a fraction of the large amount of money already earmarked to send teachers overseas [1] for a questionable but expensive training. If this is not possible, the organization can use the existing facilities either public or privately owned (See funding source below). [2]

\section{Internet access}

The program also needs a reliable Internet connection and server. The cost of Internet access for the mentors could be covered by the mentoring organization, whereas for the teachers, their schools, or the MOEC could cover it. The learning management system (LMS) could also be provided by this Ministry. This cost would not be too excessive as there are free LMSs online such as Moodle.

An issue is the availability of Internet access in rural areas especially in Eastern Indonesia, but the coverage is growing. According to the Minister for Communication and Information Rudiantara (2016), the Government continues to collaborate with providers to expand Internet coverage and stated that by the end of 2017 it would cover all areas. Although this goal is not fully achieved by then, at least all kecamatan capitals should be covered, which means a majority of the teachers can be reached since the majority of High Schools are at kecamatan levels of government.

\section{Funding resources}

As stated above, the Indonesian Government could use some of the current resources already set aside for workshops, if the Indonesian National Budget cannot provide more funding. But with $20 \%$ of the current Indonesian Annual National Budget allocation for education, it should be able to find some funding for this important project. Otherwise, companies could be approached to request some of their Corporate Social Responsibility (CSR) funds. This is not impossible if the project is managed professionally and transparently. The Indonesia Mengajar project has proven it (Personal notes from Anies Baswedan presentation during the '2012 Indonesia Update' conference, at the Australian National University).

\section{Management}

To detail the management of the system, it would take much space hence it cannot be fully discussed in this article. Therefore, only some basic points can be made here.

This mentoring system should be undertaken by an organization with the following qualities. First, it should be recognized, supervised and officially supported by the Ministry of Education and Culture (MOEC) since this is precisely designed to support its duties to improve the quality of English language teaching in Indonesia. It should also be accountable to it and the public. Secondly, the system must be organized transparently, using an integrated learning management system (LMS). This means that all the activities and transactions are recorded for evaluation and audit purposes. Thus, the system is guaranteed to be exercising best practice, and each party can rightly point to evidence that it has carried out its respective duties as expected.

\section{CONCLUSION}

The aim of this paper was to discover an innovative inservice training model for secondary school English teachers to substitute for the existing models, which have not been able to significantly improve EFL teachers' quality in Indonesia. It has been demonstrated that this system could overcome all the issues of the existing models including the ad hoc nature of the training, lack of practice and feedback, lack of time to attend, lack of the opportunity to upgrade English skills, lack of teacher input regarding the material of in-service training, and high cost. The first two issues are overcome by the regular nature of this system, the third is overcome by conducting it weekly but without the need to travel, the fourth by conducting mentoring class in English, the fifth by negotiating the material, and the last issue by employing the existing resources facilitated by the existing rules and regulations. Hence, Indonesia can trial the proposed model without negatively affecting its current account balance. It can conduct it by restructuring its current resources as instructed by the proposed model. On the contrary, it could save the Government a significant amount of money, if it re-directs the large amount of money already earmarked for sending thousands of 
teachers overseas for a mere 3-week workshop, whose effectiveness is rather doubtful.

In short, the proposed online mentoring system makes a great deal of sense to be considered as a substitute for the existing in-service training model, but surely it needs to be trialed in a small scale first so that it can be evaluated and fine-tuned to ensure its effectiveness before its Indonesia-wide implementation.

This proposal has been about Asia-Pacific, the case of Indonesia, but the idea can apply to other nonEnglish speaking countries, which are still in need of improving their EFL teachers' quality. Any country could trial the system. Their diaspora networks around the world may also be able to assist.

\section{ACKNOWLEDGMENT}

The author would like to thank Ruth Nichols for reading and commenting on the early draft of this paper.

\section{REFERENCES}

Adnan, Z. (2014). Membangun kemandirian pemelajar melalui pendekatan Genre. (Developing student independence using Genre approach). Pelbba, 18

Baswedan, A. (2016) 'Seratus persen kelulusan ditentukan oleh sekolah' (One hundred per cent school completion is determined by the schools) (a statement as made by Baswedan in his capacity as Minister of Education and Culture at a conference in Jakarta on 30/03/2015, reported in Kompas newspaper 4 April 2015. http://edukasi.kompas. com/read/2015/04/04/16000041/Mendikbud. Seratus.Persen.Kelulusan.Ditentukan.oleh. Sekolah.

Bismoko, J. (2003). Does our English teacher education need redesigning? TEFLIN Journal, 14, 58-69.

Bjorg, C. (2013). Teacher training, school norms and teacher effectiveness in Indonesia. In Surydarma, D \& Jones, G.W. (Eds.) (2013). Education in Indonesia. Singapore: ISEAS Publishing.

Brown, H.D. (2007). Teaching by principles: An interactive approach to language pedagogy (Edition 2). White Plains, NY: Pearson Education.

Davies, C. and Slattery, C. (2010). Mentoring a literature review. Melbourne: Semann \& Slattery. www. semannslattery.com. Accessed 18 March 2017.

Delaney, Y.A. (2012). Research on mentoring language teachers: Its role in language education. Foreign Language Annals, 45(S1), S184-S202. DOI: 10.111/j.1944-9720.2012.01185.x.
Emilia, E. (2005). A critical genre-based approach to teaching academic writing at tertiary EFL context in Indonesia (Unpublished doctoral thesis). Faculty of Education, Melbourne University, Melbourne.

Garvey, B., Stokes, P. \& Megginson, D. (2014). Coaching and Mentoring: Theory and Practice. Los Angeles: Sage.

Jalal, F., Samani, M., Chang, M.C., Stevenson, M., Ragatz, A.B., Negara, S.D. (2009). Teacher certification in Indonesia: A strategy for teacher quality improvement. Jakarta: Ministry of National Education and World Bank.

Lee, J.J., Murphy, J, \& Baker, A (2015). “Teachers are not empty vessels": A reception study of Freeman and Johnson's (1998) Reconceptualization of the Knowledge Base of Second Language Teacher Education. TESOL Canada journal/revue tesl du canada $133(1)$.

Lengkenawati, N. S. (2005). EFL teachers' competence in the context of English curriculum 2004: Implication for EFL teacher education. TEFLIN Journal, 16(1), 79 - 92.

Malderez, A. (2009). Mentoring. In A. Burns \& J. C. Richards (Eds.), The Cambridge guide to second language teacher education (pp. 259-268). New York, NY: Cambridge University Press.

Man, S \& Tang, E.H.H. (2012). The role of mentoring in supporting novice English language teachers in Hong Kong. TESOL Quarterly, 46(3), 472-495.

Ministry of Education and Culture (MOEC) (Indonesian) (2016). 'Terms of reference for the award to the outstanding teachers and education personnel and arts and culture activists 2016-2019'. https:// www.google.co.id/webhp?sourceid=chrome-in $\underline{\text { stant\&ion }=1 \& \text { espv }=2 \& \text { ie }=U T F 8 \# q=\text { outstandi }}$ $\underline{\text { ng+and }+ \text { dedicated }+ \text { teachers } \% 2 C+\text { education+ }}$ personnels + and + arts + and + culture + activists + LPDP+Indonesia.

Nielsen, H.D. (2003). Reforms to Teacher Education in Indonesia: does more mean better? In E.R. Beauchamp (ed.). Comparative Education Reader. New York: Routledge Falmer: 391-410.

Raihani and Sumintono, B. (2010). Teacher education in Indonesia: Development and challenges. In K. G. Karras and C.C. Wolhuter (Eds.) International handbook of teacher education world-wide: Issues and challenges, Vol I and Vol. II. Athens: Atrapos.

Rolfe-Flett, A. (2002). Mentoring in Australia: A practical guide. Frenchs Forest, N.S.W.: Prentice Hall, Pearson Education.

Rudiantara (2016) (Minister for communication and information) in a press conference at Kayong 
Utara, Solo, Central Java, on 15 October 2016 as reported by Solo Post. http://www.solopos. com/2016/10/16/2017-seluruh-wilayahindonesia-terkoneksi-internet-760880. Accessed 20 February 2016.

Parlo, S. \& Allen, J \& Rowan, L. (2017). Teacher education programs: local and global connections, Asia-Pacific Journal of Teacher Education, 45(1), 1-2, DOI: 10.1080/1359866X.2017.1265762.

State of Victoria (2013). Guide to starting a languages program. Melbourne: The Learning and Teaching Division Department of Education and Early Childhood Development. http:// www.education.vic.gov.au/Documents/school/ teachers/teachingresources/discipline/languages/ startlangprogguide.pdf. Accessed 18 March 2017.

Suharyadi, A and Sambodho, P. (2013). An assessment of Policies to improve Teacher Quality and Reduce Teacher Absenteeism. In D. Suryadarma and G.W. Jones (Eds.) (2013). Education in Indonesia (pp.139-159). Singapore: ISEAS

Sulistiyo, Urip (2015). Improving English as a foreign language teacher education in Indonesia: The case of Jambi University. (Unpublished doctoral thesis). RMIT, Melbourne. https://researchbank. rmit.edu.au/eserv/rmit:161521/Sulistiyo.pdf.

Sukyadi (2015). The teaching of English in Indonesia. In
B. Spolsky and K. Sung (Eds.) (2015). Secondary school English education in Asia from policy to practice (pp.162-191). London \& New York: Routledge.

Sumintono, B. \& Subekti, N.B. (2015) Teacher inservice training and re-training in Indonesia. In Konstantinos G. Karras and C. C. Wolhuter (eds.) (2014). International handbook of teacher education training and re-training systems in modern world (pp. 255-272). Cyprus: Studies and Publishing.

Surydarma, D \& Jones, G.W. (Eds.) (2014). Education in Indonesia. Singapore: ISEAS. Indonesia Mengajar (n.d.). Visi dan Misi Indonesia Menagajar (Vision and Mission of the Indonesia Mengajar). https://indonesiamengajar.org/ tentang-indonesia-mengajar/visi-dan-misi/. Accessed 6 December 2016.

Widodo, H.P. (2016) Language Policy in Practice: Reframing the English Language Curriculum in the Indonesian Secondary Education Sector. In R. Kirkpatrick (Ed.). English Language Education Policy in Asia. Switzerland: Springer International Publishing.

Yazan, B. (2010). "You Learn Best When You're in There": ESOL Teacher Learning inthe Practicum. The CATESOL Journal, 27(2), 201. 